\title{
Integration of Ethical Values into Activity-Based Budgeting
}

\author{
Pierluigi Santosuosso ${ }^{1}$ \\ ${ }^{1}$ School of Economics, Sapienza University of Rome, Italy \\ Correspondence: Pierluigi Santosuosso, School of Economics, Sapienza University of Rome, Rome, Italy. Tel: \\ 39-6-4976-6460. E-mail: pierluigi.santosuosso@uniroma1.it
}

Received: July 29, 2013

doi:10.5539/ijbm.v8n20p1
Accepted: August 23, $2013 \quad$ Online Published: September 22, 2013

URL: http://dx.doi.org/10.5539/ijbm.v8n20p1

\begin{abstract}
Despite appeals from public opinion all over the world for the development of ethics in business and the widespread adoption of a Code of ethics by many firms, the integration of ethical values into the corporate planning process has received little attention either in real life or in research literature. In order to overcome the gap between ethical principles and practice, this study underlines some key points which could help the integration of values into Activity-Based Budgeting: identifying ethical values, creating an Ethical framework, examining the distinctive parts of actions, choosing a preference order for values, incorporating the values into each single element of every activity. The approach based on activities allows managers to give visibility to those objectives with an ethical dimension and incorporates them analytically into the budgeting system.
\end{abstract}

Keywords: ethical values, ethical decision making, activity based budgeting, planning process

\section{Introduction}

The subject of business ethics has received a great deal of interest from public opinion, consumers, politicians, managers and economists all over the world. The word "ethics" is now widely used in conferences and newspaper articles and there is a growing literature on business ethics (Brenkert, 2010), whilst the adoption of a Code of ethics by an increasing number of firms around the world (Kaptein, 2004; Schwartz, 2005; KPMG Forensic, 2008; Singh et al. 2011) confirms the importance of this issue for managers and entrepreneurs.

However, does a Code encourage the achievement of corporate objectives with an ethical dimension? Are managers and employees running their firms more ethically? The question of the effectiveness of a Code of ethics has been addressed in several studies. Literature reviews on this issue have been made by Schwartz (2001, 2004), Lere \& Gaumnitz (2003, 2007), B. Stevens (2008), Kaptein \& Schwartz (2008), Ho (2010), Singh (2011) and Kaptein (2011), to name just a few. The research literature, however, provides conflicting results; it is not clear what effect a Code of ethics has on decision making and what factors influence the effectiveness of a Code (Helin \& Sandström, 2007; Kaptein \& Schwartz, 2008; Singh, 2011). The issue is not purely academic, without any practical consequences. As ethical values, or simply values, govern managers' and employees' behaviors, ethical matters have economic, social and legal effects on the firms' performance and on society as a whole. Despite the appeals for ethics in business and analyses of the factors that are likely to reinforce the effectiveness of ethical codes, malpractice does not appear to be abating (Webley \& Werner, 2008; Brenkert, 2010). A high percentage of employees in U.S. companies testify to misdeeds within their firms (KPMG Forensic, 2008; Ethics Resource Center, 2012). Even today we are witnessing varied and numerous episodes of misconduct, such as the violation of workplace health and safety rules, the infringement of environmental standards, the mismanagement and misuse of an organization's resources and company time, false or deceptive sales practices and lying to employees (KPMG Forensic, 2008; Ethics Resource Center, 2012). Ethical compliance programs, such as ethical codes, policy statements, speeches, systems for reporting malpractice, do not seem to reduce legal violations (McKendall, DeMarr \& Jones-Rikkers, 2002).

This has led researchers, businessmen and politicians to analyze the issue in the hope of finding better solutions. The purpose of this work is to make values more visible and tangible in order to make them an integral part of the corporate planning process and therefore overcome the gap between ethical principles and practice. "The things included in the measurement become relevant; the things omitted are out of sight and out of mind" (Drucker, 1954). The integration of values into the planning process, however, is not an easy task. On the one hand, managers have to identify values for their firms which will satisfy the requirements of moral judgment; on 
the other hand, effective budgeting needs an approach that allows the inclusion of objectives with an ethical dimension into a concrete plan of action. This paper will propose that an effective way of integrating values into budgeting through Activity-Based Budgeting. It proposes that planning should focus on activities in which activities are identified and organized into broader processes to support strategic goals.

The article is organized as follows: the second section provides a brief review of the literature; the third section describes the identification process of corporate ethical values; the fourth section explains the need for establishing a preference order for ethical values; the fifth section presents their integration into Activity-Based Budgeting; the sixth section describes a case study; the last section summarizes the steps of the integration process and presents some concluding remarks.

\section{Literature Review}

The decision-making process is an old issue, as old as the origin of ethics (the words moral and ethical are used here as synonymous, the difference simply being due to their etymology). Philosophers, economists and politicians have debated about human behavior for centuries. Over the course of history, many moral doctrines have been developed, including utilitarianism, eudaemonism, emotivism, historicism, ethical relativism, deontological duty-based approach and virtue ethics (Shaw, 2005; Velasquez, 2006; Weiss, 2006). Moral doctrines have not only explored theoretically the concept of good and bad, but have also examined in detail the decision-making process. According to the studies of Thomas Aquinas in the 13th century (Summa Theologica, Prima Secundae), the decision-making process can be broken down into elementary stages, driven by the intellect and the will (De Finance, 1997). Firstly, the idea of an ethical value is formed and the will accepts it (voluntas); an opinion is formed about the possibility of putting into practice the ethical value (intentio); an analysis for an appropriate solution for the purpose is made (consilium); certain solutions are accepted (consensum); the decision about the best solution is chosen (electio); the order to implement the chosen solution is given (imperium); the chosen solution is executed (usus); the material good is used (fruitio).

More recently, the problem of ethical decision-making has been addressed by many researchers. Much of the research, developed on the basis of psychological theories (Kohlberg, 1969), suggests theoretical models containing different phases (Rest, 1986; Trevino, 1986; Ferrell \& Gresham, 1985; Hunt \& Vitell, 1986; Bommer et al., 1987; Dubinsky \& Loken, 1989; Stead, Worrell \& Stead, 1990; Jones, 1991). In one of the most famous and frequently cited models, ethical decision-making is composed of four stages: recognizing an ethical issue, making moral judgments, establishing moral intentions and engaging in moral behavior (Rest, 1986). The stages in the models are usually supplemented by various individual characteristics and organizational forces that influence decision-making, as for example, ego strength, field dependence and locus of control, immediate job context, organizational culture and characteristics of the work itself (Trevino, 1986), social, government and legal environments, professional and personal environments, individual qualities (Bommer et al., 1987). Other models, based primarily on experience gained in professional practice, propose a variety of steps to identify and resolve ethical dilemmas. Following the identification of the ethical dilemma and the gathering of information essential for decision-making, these models emphasize the analysis of alternative actions and their consequences (Rocco Cottone \& Claus, 2000). These models are based mainly on the Deontological approach (when actions are judged morally right depending on how well they conform to a particular set of principles) or on the Consequentalist approach (when actions are judged morally right in relation to their consequences).

In addition to the models proposed by academics and practitioners, the ethical decision-making process has been investigated in large numbers of surveys which aim to verify empirically a wide range of factors that affect the process, such as the philosophical conception of morality, cognitive moral development, gender, education and work experience, age, nationality, the cultural and ethical climate, the rewards and sanctions system, religion, moral intensity, the kind of Code of ethics, industry type, organizational size etc. (Ford \& Richardson, 1994; Loe, Ferrell \& Mansfield, 2000; O'Fallon \& Butterfield, 2005). The surveys are based on an analysis of the ethical "perception" of managers, employees and students faced with hypothetical ethical dilemmas. The findings are mixed, inconclusive and are open to criticism about the identification of a representative sample, the reliability or validity of measures, the methodological procedures for understanding an individual's moral reasoning (Randall \& Gibson, 1990; Weber \& McGivern, 2010) and, more generally, about the impossibility of applying ethical theory to real life (Barlett, 2003). Without going into a detailed analysis of the research literature, it is nevertheless worth noting that the main limitation of much of the empirical research lies indeed in the concept of ethical "perception". The "perception" of a hypothetical dilemma expresses a mere opinion of the people interviewed about some ethical issues; action is instead the expression of a moral judgment in the strict sense. We will summarize the concept of moral judgment in section three. 
Ethical decision making is only part of the integration of values into the planning process. It is principally concerned with specific decisions taken by individuals, whilst real integration of ethical values drives the organization as a whole towards multiple objectives with an ethical dimension.

In order to overcome the gap between ethical principles and practice within firms, two main approaches have been suggested, firstly, the creation of an ethical corporate culture and secondly, the introduction of an effective ethics policy (Webley \& Werner, 2008). As far as the creation of an ethical culture or climate in concerned, there are several mechanisms that allow managers to shape a values-based organization. These include the charismatic role of top managers, leadership styles, the development of ethics programs by communicating and monitoring ethical values, good organizational practice (Ferrell, Fraederic \& Ferrell, 2011), the discussion of moral issues as part of the manager's job (Water \& Bird, 1987), setting up clear standards of ethical behavior, recognition and rewarding of behaviors that sustain organizational values, feedback, awareness of individual differences, (Grojean et al., 2004), the behavior of top management as an example for the rest of the organization (Adam \& Rachman-Moore, 2004), ethics code awareness (Valentine \& Barnett, 2003), ethics training (Valentine, 2009), an ethical climate of benevolence (Cullen et al., 2003). Although ethical culture and ethical climate play an important role in ethical decision-making (Trevino, Butterfield \& McCabe, 1998), empirical studies have not yet provided conclusive results (Loe, Ferrell, \& Mansfield, 2000; O'Fallon \& Butterfield, 2005; Helin \& Sandström, 2007; Kaptein \& Schwartz, 2008).

As regards the need for an effective ethics policy, less attention in the research literature has been given to approaches that actually incorporate values into corporate planning (Helin \& Sandström, 2007) than to studies on the development of an ethical climate and culture. Robin and Reindenbach (1987) suggested the integration of ethical and socially responsible plans into strategic marketing planning based on a model consisting of four stages in which each stage is divided into two parallel processes: the identification of ethical values and the development of a marketing strategy. Guerrette (1988) set out a five-step development plan of management strategies in which emphasis was placed on the need for continuing professional training and the reformulation of corporate strategy in accordance with a Code of ethics and the corporate value statement. Hosmer (1994) recommended that ethics must be part of the planning process in order to enhance trust, commitment and effort among stakeholders. Rampersad (2003) provided a strategic management model in which the personal goals of people were integrated into the organizational Balanced Scorecard aligning the personal ambition of managers and employees with the shared organizational mission. Bonn and Fisher (2005) underlined the importance of a flexible approach towards the development of guidelines for ethical conduct as well as structures and processes for monitoring and improving ethical behavior. Ferrell, Fraedich and Ferrell (2011) suggested that ethical compliance can be ensured by organizing activities to reach corporate objectives.

\section{Identification of Corporate Ethical Values}

Many moral doctrines have investigated the concept of good and bad in the course of time. Rather than provide an overview of the philosophical thought, this paper will outline some key arguments related to ethical decision-making. Regardless of the philosophical conception of morality, individuals are moral entities that decide and act on the basis of their moral judgment. As shown in several ethical decision making models (Rest 1986; Trevino 1986; Hunt \& Vitell, 1986; Dubinsky \& Loken, 1989; Jones, 1991) and in valuable studies on Ethics (De finance, 1997; Pinckaers, 1992), moral judgment is the linchpin of decision-making and has a key role in the workplace for managerial work (Loviscky, Trevino \& Jacobs, 2007; Street, 2001).

The choice of what constitutes "good and bad" is not left to the whim of managers and employees, but is the result of moral judgment in the strict sense of the word. Values originate from an examination of our behavior and/or the behavior of other people who are directly or indirectly involved in the business (employees, consumers, investors, suppliers and other stakeholders). In a person with a developed sense of moral reasoning, we can observe a reaction of approval for behavior deemed moral or a response of disapproval for behavior deemed immoral: admiration or disapproval of the behavior of others, gratification or remorse for our behavior. These experiences are known as moral experiences (De Finance, 1997) and on the basis of these experiences, a person begins to formulate moral judgments about what is good and what is evil. Through the awareness of values, people acknowledge the incompleteness of their own existence and the need to put them into practice. Values appear as good that needs to be done; a "duty to be" which demands a "must do". People are often heard saying "I have to help that person" or "I ought to behave in this way". Moral judgment guides an individual's own actions and suggests behaviours that should be adopted by others (Leavit et al., 2012). More specifically, moral duty persuades people to do good. Actions that are needed for its achievement reinforce positive experiences of admiration or gratification and free them from the experience of remorse or moral scandal. Judgment of the "right reason" (De Finance, 1997) shows what good, or human values, deserve to be pursued. 
Moral duty plays a key role in the ethical decision process (Haines, Street \& Haines, 2008) although it has received minimal emphasis in the research literature. And, fundamental to the decision-making process is the presence of freedom, which is also rarely discussed in business theory (Dierksmeier, 2011). Free will is a basic concept addressed by philosophers in the course of many centuries (Kane, 1998; O'Connor, 2012). Although the concept could have different meanings, freedom is essentially considered here as freedom of acting without constraints (Pinckaers, 1992). Acting with free will, is the main requisite for moral reasoning in ethical decision-making. In the absence of freedom, moral duty cannot exist and any action that follows is devoid of any willingness to act (Drascek \& Maticic, 2008).

The identification of the values according to the ethical decision process mentioned above can lead to the editing of an "Ethical framework". The Ethical framework lists a series of values that deserve to be affirmed. For a better analysis and updating of the Ethical framework, managers can classify values in order to highlight some major features. This paper suggests at least two general criteria for this classification. The criteria enable us to understand and detect the objective and subjective aspects of ethical values.

The first criterion is based on the objective nature of ethical values, which range from the physical to the spiritual nature of mankind. Biological values are related to the basic needs of every human being (e.g. food and health) and sensitivity values are represented by the pain and pleasure that comes from the senses (e.g. fatigue or rest, fear or serenity). Economic values are directly related to the use of human faculties to obtain economic goods (e.g. wealth creation, values related to the acquisition of professional skills, development of the personality through the use of power and success), whereas social values emerge when we consider the individual in the community where he or she lives (e.g. the ability to maintain relationships, the aptitude to lead an organization or settle disputes). Other values include aesthetic values related to the attractiveness of something a person has created (e.g., the beauty of a product, the pleasantness of the place of work), knowledge which concerns the knowledge of truth or falsehood (e.g. the values of experience, education, competence, accuracy of information) and the values concerning the will and the natural ability of people to achieve their own ends (e.g. temperament, perseverance, courage). Moral values in a strict sense are concerned with making a moral judgment and behaving in an honest way consistent with this judgment (dependent on the freedom of choice). Finally, one cannot ignore religious values (e.g. an organization that does not discriminate employees, suppliers or customers for their religion).

The second classification criterion is made according to the type of stakeholders, such as employees, suppliers, customers, investors, the community and all other persons not yet affected by corporate policy. Although an Ethical framework can also specify the names of employees, customers or suppliers involved in the business activity, this classification is not made in order to find solutions that satisfy the specific interests of these individuals, but to identify the values of people involved in the activity of the firm. Between what people want and values there is obviously a significant difference: not all stakeholders' requests correspond to the values and vice-versa not all values have been requested by stakeholders.

An Ethical framework differs from a corporate Code of ethics and from other principles and guidelines adopted by Intergovernmental organization (Human Rights Council, 2011) in at least two ways. First, the Code of ethics contains a wide range of general standards that apply to firms of any kind, as several empirical studies reveal (Cressey \& Moore, 1983; Carasco \& Singh, 2003; Kaptein, 2004; Singh et al., 2011). Although the Ethical framework may include a broad spectrum of general values, it sets out in detail some values and all specific circumstances relating to persons, causes, effects, mode and places that are relevant to describe them. Consequently, the number and the range of values can differ significantly according to the various characteristics of the firms. Second, the Ethical framework is subject to being updated when a moral judgment suggests changes and additions. A change in a moral judgment may arise from an analysis of the output of budgeting and/or from the knowledge of other events and behaviors according to the cognitive process described in the second section.

These main characteristics show that the Ethical framework, as a dynamic and not static document, represents the first step in effective corporate planning with an ethical dimension. This allows managers to begin to close the gap between ethical principles and planning for the specific firm.

\section{Preference Order and Consistency among Ethical Values}

It is unlikely that all the values shown in the Ethical framework can be achieved to the same degree. There are a number of reasons why all the values cannot be achieved equally. A first set of constraints is related to the quantity and quality of the factors of production the firm needs for achieving its goals, e.g. lack of funding, lack of workers' skills or difficulties in finding material goods of high quality. A second set of reasons is due to 
external factors beyond the control of the firm, e.g. a new competitor's entry into the market, the fluctuation of consumer demand, the introduction of new laws and regulations, riots or climatic events.

Decision making under constraints has been widely addressed in the economic literature, especially in the operational research area. The description of ethical issues in decision-making models has recently received a great deal of interest by in increasing number of studies (Ormerod \& Ulrich, 2013; Mingers, 2011). Although the operational research methods can help managers to maximize the performance of a system under constraints, difficulties in fully realizing the ethical values could lead managers to give priority to some values over others. Some values may be totally achievable, whilst others only partially, as regards the number of people involved or to what extent the objectives are achieved. Some values may also be immediately realized, but postpone the achievement of others. In other words, during the course of the planning process, managers have to choose a preference order among ethical values. In the presence of constraints, the choice is obviously complex, but necessary. It is difficult to distinguish between good and bad and it is even more difficult to identify which value should be achieved before others. The "Theory of value" (Schroeder, 2012; Hart, 1971), also called axiology, explores this complex issue through the investigation of the nature of human values.

Without addressing the philosophical issue, the key point that this paper wants to stress is the existence of a preference order among values. More specifically, in spite of the attempts to deny any universal values by ethical relativism (De Finance, 1997; Shaw, 2005; Weiss, 2006), it is evident that a moral judgment tends to establish a preference order among values in the midst of an ethical dilemma. For example, should resources be used for "an exhibition of art" (an aesthetic value) or should they be used to pay medical researchers to develop "scientific knowledge" (the value of knowledge)? There seems no doubt about the existence of a hierarchy of values. It is likely that many managers and entrepreneurs with a developed moral reasoning would choose to use the resources to pay researchers for advances in scientific knowledge.

For the resolution of this complex issue, it is clear that the nature of the values involved in an ethical dilemma (whether biological, economic, social, aesthetic and so on) is not sufficient to decide the priorities to be followed. For example, if substantial investments can increase the already available scientific knowledge only slightly, should the investment be postponed in order to affirm an aesthetic value? Clearly, the answer depends on many other factors. The complexity of the decision-making process increases when we are faced with a real life ethical dilemma where many values are involved and various effects occur.

The criterion by which managers may identify the preference order is set by moral judgment in the sense specified in section three. The moral duty of people, whose freedom of choice is not impaired or limited, allows the identification of values and determines the intention to act for their achievement. The solution to the ethical dilemma involving the preference order requires a deep examination of the problem. More specifically, a fully accomplished moral judgment needs a preliminary analysis of actions that are going to be implemented.

The analysis can be made by an examination of four distinctive parts of the action (Vendemiati, 2004). Firstly, we consider its ontological aspect. This describes its objective nature, e.g. the purchase of a machine, the sale of a product, the hiring or firing of employees. The second aspect that characterizes the act is the so-called finis operis (the purpose of the action). An action can have different purposes, e.g. the purchase of a machine can be made to produce weapons or to produce cars, the firing of an employee can be made to reduce fixed costs or to deliberately harm the worker. The third aspect of the act to be considered is the effects that it may generate. There is obviously a wide range of effects, as for example, the purchase of a machine can cause environmental damage or an improvement in employees' working conditions, whereas the advancement of an employee's position has a positive impact on his or her life, but could have a negative effect on those of other workers. The fourth aspect of the act is constituted by the so-called finis operantis (the motive of the act). According to St. Thomas's well-known classification (De Finance, 1997), the objective of an action could be the pursuit of pleasure (physical or psychological), the affirmation of good as an end (e.g. the production and distribution of drugs to poor countries, education for deserving students) or the search for good as a means to achieve other goals (e.g. making profit can be pursued in order to enjoy the consumption of material goods, to gain the esteem of other people or to invest in scientific research).

The analysis of the different parts of actions allows us to make a moral judgment in a complete way and avoid three types of risks. The first concerns making the right choice about the preference order of values. A deep analysis of the single parts of the actions is necessary because certain aspects of behaviors introduced in order to achieve the values may have to be examined so that a correct moral judgment may be made. The second is related to the likelihood that constraints may induce, voluntarily or involuntarily, managers to assert the Machiavellian "the end justifies the means" principle, whereas all objectives should be consistent with the values shown in the 
Ethical framework. In other words, in order to achieve the values shown in the framework in a consistent manner, the analysis should prevent an action from stopping the assertion of other values. Thirdly, we cannot ignore the ethicality that should be respected in budgeting. The ethical characteristics of budgeting are not limited to its content, but should also include the way it is prepared. In the research literature, the ethics of budgeting has been analyzed mainly as regard budgetary participation and budgetary slacks (Hobson, Mellon \& Stevens, 2011; Libby, 2001; Lau \& Tan, 1996; Casey Douglas \& Wier, 2000).

\section{Integration of Values into Activity-Based Budgeting}

"The real difficulty lies indeed not in determining what objectives we need, but in deciding how to set them" (Drucker, 1956). Goals that are not included in the planning process are not visible and will not be achieved, especially if their achievement requires the co-ordination of different actors and the use of resources.

In order to determine what will be done, by whom, how and when, the identification of values should subsequently be followed by their integration into the planning process, or to be more precise, into the budgeting process. The integration of objectives with an ethical dimension into budgeting is however a complex issue. Budgeting, in its most traditional form, has recently become the subject of criticism and debate about its numerous dysfunctional aspects put forward especially by management consultants (Ekholm \& Wallin, 2000) and outlined by describing practical business experiences (Wallander, 1999). It focuses on costs rather than on value creation (Hope \& Fraser, 2000), is frequently reduced to the role of financial forecasting based on last year's costs and then simply adjusted to account for revenue growth or decrease (Bunce, Fraser, \& Woodcock, 1995). Furthermore, it is not linked to strategy, it encourages gaming and perverse behaviours (Jensen, 2003), is time-consuming (Hope \& Fraser, 2003), leads to sub-optimal performances, does not consider the workload of the activities, there is a lack of commitment, it does not reflect changes in the firm's organization, outputs are not visible (Brimson \& Antos, 1999) and it is expensive (Schmidt, 1992). On the other hand, even though these limitations have been found as well as many other problems which have been widely examined in the research literature (e.g. budgetary slacks, budgetary participation, the effect of information asymmetry within the process), traditional budgeting still plays an essential role in the corporate planning system. Rather than abandoning it, attempts have been made to improve traditional budgeting (Libby \& Lindsay, 2010; Ekholm \& Wallin, 2000).

This paper suggests that an ethical dimension can be better integrated into planning by preparing the budget on the basis of business activities. Activity-Based Budgeting is one of the most well-known approaches aiming to overcome the limitations of traditional budgeting (Hansen, Otley \& Van der Stede, 2003). It proposes that planning should focus on activities in which activities are "simply the work that is performed in transforming inputs into outputs" (Brimson \& Antos, 1999). Activities are identified and organized into broader processes to support strategic goals. This model incorporates the mechanisms that have been outlined for achieving the key objectives of advanced budgeting (Bunce, Fraser, \& Woodcock, 1995). Activity-Based Budgeting has several advantages over traditional budgeting which have been highlighted in studies, including the identification of the causes of imbalances, inefficiencies and bottlenecks, the detection of capacity issues, the perception and communication of information by lower-level managers and employees (Hansen et al., 2003), a clear relationship between budgets and strategies, the assessment of detailed expenses across organizations, ongoing performance improvements (Schmidt, 1992). Moreover, activities are easily planned, activities can be assessed for their contribution to the firm's mission and also be divided into value and non-value activities (Marcino, 2000).

Rather than being a panacea for all firms, Activity-Based Budgeting could be a suitable approach for planning activities with an ethical dimension. It enhances the sophistication of the operational planning system (Hansen, 2011) that is needed in budgeting for managers who aim to establish "how" to achieve "qualitative" objectives.

More specifically, in order to integrate values into the planning process, this paper proposes each activity in budgeting be structured on the basis of a set of key elements as listed below:

1) The input of the activity (the event that starts work in that activity);

2) The resources that are needed in the activity (equipment, software etc);

3) The number and names of employees;

4) The tasks assigned to employees, reward systems, hours of work and the deadlines to be observed;

5) The type of organizational structure;

6) The information required by employees to do their job; 
7) The output (or outputs) of the activity.

These elements are all interrelated in order to produce the output(s). Furthermore, all the activities are organized in a system so that the output of one activity is usually the input of other activities; resources, employees and information needed for achieving the output can also be shared by a number of activities.

The key factor in the preparation of a budget with an ethical dimension is the analytical introduction of values into the elements of the activities. To clarify this point, let's consider the following examples. In order to favor environmental protection, the purchasing activity can be designed to buy high-quality resources (element n.2), such as raw materials, machinery and equipment, with a low pollution impact. To safeguard the health of workers, the company may plan to reduce working hours (element n.4) in the manufacturing process. To ensure equal conditions for employees, the turnover in the manufacturing activity can be organized (element n.5) to give a fair distribution of the workload. To provide information on the impact of production on the environment, it may be necessary to design a public relations activity with the specific output (element n.7) of providing adequate information to the public. The elements of the activities should be set out formally in software for managerial applications. The system is simulated in order to analyze the efficiency and effectiveness of the overall activities, which will highlight the strengths and weaknesses of the overall system. The software provides detailed operational and financial reports on each activity and on the system as a whole (including the amount of resources used, the time for completing the cycles of processes, fixed and variable costs, sales revenue, etc).

The analysis and the systematic planning of activities, in the way mentioned above, offer several advantages. We underline at least three main benefits. 1) Values often cannot be expressed in quantitative terms. Ethical goals are not easily incorporated into the budget in its traditional form, but they can be included in activities as output if we adopt Activity-Based Budgeting. Some of these can be measured by quantitative indicators, whilst others can be expressed in qualitative terms (e.g. selection for promotion based on merit, the disclosure of very complete information, a fair distribution of resources). This gives visibility to the outputs and reinforces managers' commitment to their attainment. 2) Activity-Based Budgeting allows us to organize activities accurately in order to obtain the output. As pointed out earlier, a clear definition of the activity's elements helps to put into practice the ethical values outlined in the ethical values framework so that the tasks that the employees are responsible for, the type of organization, timing, resources and other elements of the activity are visible and planned in a precise and coordinated way. 3) Activity-Based Budgeting is easily updated by introducing new activities or changing the elements of the existing activities. The updating can be preceded by a simulation process. Focusing the analysis on the operations to be performed and on the financial results that follow, the simulation allows the firm to modify the activities' elements and the system as a whole before implementing the plan.

\section{Case Study}

The integration of Ethical values into Activity-Based Budgeting was examined by implementing the model in a small family-owned company which provides building services in central Italy. Edilizia Moliri, a private limited company, specializes in historic preservation and interior renovations. The founder, along with his family, shows the highest dedication in running his firm in an ethical manner.

Table 1 shows, in a simplified version, the system of corporate activities implemented in this firm. "Business planning" deals with the identification of the Ethical framework, the definition of a preference order and the consistency among ethical values, the preparation of budget and the organization of overall activity. As described in section five, the outputs of the other activities are the inputs of downstream activities; resources and employees are also shared by a number of activities (e.g. staff working in the "Business planning" activity is involved in the other activities described in table 1). 
Table 1. Edilizia moliri limited, business activities

\begin{tabular}{|c|c|c|c|c|c|c|c|}
\hline Activities & Input & Resources & Personnel & $\begin{array}{l}\text { Task \& } \\
\text { Reward }\end{array}$ & Organization & Information & Output \\
\hline $\begin{array}{l}\text { Business } \\
\text { Planning }\end{array}$ & $\begin{array}{l}\text { At least once } \\
\text { a year }\end{array}$ & $\begin{array}{l}\text { Technical } \\
\text { advise }\end{array}$ & $\begin{array}{l}\text { Mr. Moliri } \\
\text { Mr. Smith } \\
\text { Ms. Brown } \\
\text { Mr. Jones }\end{array}$ & Dividend & $\begin{array}{l}\text { Team } \\
\text { structure }\end{array}$ & $\begin{array}{l}\text { Personal } \\
\text { experience, } \\
\text { consultants }\end{array}$ & $\begin{array}{l}\text { Ethical } \\
\text { Framework, } \\
\text { Budget }\end{array}$ \\
\hline $\begin{array}{l}\text { Client } \\
\text { Service }\end{array}$ & $\begin{array}{l}\text { Clients } \\
\text { contact }\end{array}$ & Advertising & Mr. Smith & Full-time & - & $\begin{array}{l}\text { Market } \\
\text { research }\end{array}$ & $\begin{array}{l}\text { Client } \\
\text { agreement }\end{array}$ \\
\hline $\begin{array}{l}\text { Architectural } \\
\text { Design }\end{array}$ & $\begin{array}{l}\text { Client } \\
\text { agreement }\end{array}$ & $\begin{array}{l}\text { Software, } \\
\text { consumables }\end{array}$ & $\begin{array}{l}\text { Ms. Brown } \\
\text { Mr. Doe } \\
\text { Mr. } \\
\text { Johnson }\end{array}$ & $\begin{array}{l}\text { Full-time } \\
\text { Full-time } \\
\text { Traineeships }\end{array}$ & $\begin{array}{l}\text { Horizontal } \\
\text { structure }\end{array}$ & $\begin{array}{l}\text { Customer } \\
\text { needs }\end{array}$ & $\begin{array}{l}\text { Architectural } \\
\text { project }\end{array}$ \\
\hline $\begin{array}{l}\text { Manufacturing } \\
\text { Process }\end{array}$ & $\begin{array}{l}\text { Architectural } \\
\text { project }\end{array}$ & $\begin{array}{l}\text { Raw material, } \\
\text { equipment }\end{array}$ & $\begin{array}{l}\text { Mr. Jones } \\
\text { Four } \\
\text { workers }\end{array}$ & $\begin{array}{l}\text { Full-time } \\
\text { Piece work }\end{array}$ & $\begin{array}{l}\text { Vertical } \\
\text { structure }\end{array}$ & $\begin{array}{l}\text { Technical } \\
\text { guides }\end{array}$ & $\begin{array}{l}\text { Building } \\
\text { renovation }\end{array}$ \\
\hline $\begin{array}{l}\text { Control } \\
\text { of Activities }\end{array}$ & $\begin{array}{l}\text { At least once } \\
\text { a month }\end{array}$ & $\begin{array}{l}\text { Travel } \\
\text { expenses }\end{array}$ & Ms. Haven & Piece work & - & $\begin{array}{l}\text { Analysis of } \\
\text { results }\end{array}$ & $\begin{array}{l}\text { High quality } \\
\text { service }\end{array}$ \\
\hline
\end{tabular}

Note: the table shows the main information on the business activities. Tasks' description, working hours, wages and the cost of resources are not shown in this table. With the exception of the founder, the names of employees have been changed.

The system was modeled with a simulation software tool (Rockwell Automation, 2006) that allows the user to create a simulation model and run experiments. Each activity was organized in more detail than is briefly set out in Table 1. For example, as regards the "Client Service", it was specified the minimum time in which the work could be done (5 days), the most likely period of time to perform the work ( 8 days) and the maximum duration of the activity (15 days). Furthermore, the model incorporates other additional variables such as: the daily workload ( 8 hours per day), the hourly wage (12 euro), advertising expenses (300 euro on average for each contact with the client), the percentage of contracts that actually follow the estimates (66\%), the proportion of wages and resources while they are actually used in the activity and while they are not used because of idle time. The other business activities, shown in the table 1, have been defined in detail in a similar way.

The integration of ethical values into budgeting was carried out by a detailed definition of these variables, here called the elements of the activities. More specifically, the budget of the small firm here examined was prepared for achieving various ethical objectives. To help young unemployed people, the firm offers traineeships in the "Architectural Design" activity; in order to favor the environmental protection, the "Manufacturing process" uses high quality materials whilst the adequate number of workers here employed permits to reduce fatigue, to protect their health and to respect their dignity; employee participation in "Business planning" promotes self-esteem and group cohesion. Furthermore, the "Control of activities" gives the opportunity to affirm other important values: the clients satisfaction and the protection of economic value of their properties.

The cost of these measures and other important information were examined by running the simulation. The software (Rockwell Automation, 2006) generates numerous technical and financial reports. Table 2 shows some of the average results of the simulation on the basis of ten iterations. The software also provides reports on the specific resources (workforce and material goods) showing the total cost, their actual use and downtime.

On the basis of Activity-Based Budgeting, administrators do not focus on costs and revenues, but on things to do, how to achieve them and their timing to be met. This is an easy and effective way for developing a plan; the administrator's choices are quickly implemented in the budget and are analyzed in detail using a software tool that permits the identification of the causes of imbalances, bottlenecks and inefficiencies. The method is especially suitable in the case of objectives not expressed in quantitative terms, as often happens with objectives having an ethical dimension. For example, increasing job satisfaction is a goal that can be achieved through various measures. The administrator can intervene on working hours, ways of participating in meetings, the quality of equipment and raw materials and on other elements of the activities. Based on the simulation results, the administrator verifies if these elements could be achieved and if necessary intervenes again in order to obtain the desired effect. Unlike the traditional planning, these aspects are formally incorporated into budgeting. Although many companies are used to define their business activities to be carried out, the objectives not expressly stated in the budgeting, and generally in the measuring processes, become irrelevant as time goes by. 
Table 2. Edilizia Moliri limited, simulation report

\begin{tabular}{|c|c|c|c|c|c|c|c|}
\hline Activities & $\begin{array}{l}\text { Input } \\
\text { (No.) }\end{array}$ & $\begin{array}{r}\text { Output } \\
\text { (No.) } \\
\end{array}$ & $\begin{array}{l}\text { Time per } \\
\text { entity }(\mathrm{h})\end{array}$ & $\begin{array}{r}\text { Total time per } \\
\text { entity }(\mathrm{h})\end{array}$ & $\begin{array}{r}\text { Total wait } \\
\text { time }(\mathrm{h})\end{array}$ & $\begin{array}{r}\text { Total cost per } \\
\text { entity }(€)\end{array}$ & $\begin{array}{r}\text { Total cost } \\
(€) \\
\end{array}$ \\
\hline Business Planning & 3.1 & 2.4 & 158 & 357 & 467 & 6104 & 13802 \\
\hline Client & 13.7 & 13.3 & 76 & 1004 & 1221 & 1207 & 16044 \\
\hline \multicolumn{8}{|l|}{ Service } \\
\hline Architectural & 8.3 & 7.1 & 159 & 1120 & 705 & 4717 & 33190 \\
\hline \multicolumn{8}{|l|}{ Design } \\
\hline Manufacturing & 7.1 & 6.1 & 199 & 1198 & 515 & 25956 & 157052 \\
\hline \multicolumn{8}{|l|}{ Process } \\
\hline $\begin{array}{l}\text { Control of } \\
\text { Activities }\end{array}$ & 6.1 & 5.6 & 82 & 467 & 0 & 1331 & 7568 \\
\hline Total cost for the ac & e of res & & & & & & 227656 \\
\hline Total cost of resour & actuall & & & & & & 55391 \\
\hline
\end{tabular}

Note: entities are the items (document, works etc) that are produced by activities.

\section{Summery and Conclusion}

Although a great interest in business ethics has been shown recently in the literature and an increasing number of firms all over the world have adopted a Code of ethics, episodes of misconduct do not appear to be abating.

To overcome the gap between ethical principles and practice, this paper has suggested some basic stages that can help the integration of values into corporate budgeting. In addition to the laudable initiatives to promote an ethical corporate culture, the need for effective integration is essential, since the values are likely to be ignored in business activities unless they are made visible in a concrete plan of action. For this purpose, this paper suggests an approach that needs two general requirements: first, the managers' ability to identify values concerning people who have a direct or indirect relationship with the firm; second, the task of making a detailed account of the values in Activity-Based Budgeting. More specifically, this paper proposes that budgeting should consider at least five stages.

1) The first stage concerns the identification of ethical values. The choice of what constitutes a "value" should not be left to the whim of managers and employees, but should be the result of a moral judgment in the true sense. In brief, moral duty helps people who have a developed moral reasoning and enjoy freedom of choice to correctly identify values and persuade the will to act for their achievement.

2) The identification of ethical values leads to the creation of an Ethical framework. An Ethical framework, in contrast with the contents of a Code of ethics, shows in detail the values and circumstances concerning people, causes, effects, mode and places that are relevant for describing them. The ethical framework, as a dynamic, not static document, represents the first document for effective corporate planning with an ethical dimension.

3) The decision process needs a prior examination of the whole structure of an action, in all its distinctive parts, for the achievement of the values that are going to be implemented in budgeting. No action taken to introduce a value should prevent the affirmation of other values, whether in the system of values shown in the Ethical framework or the values specifically involved in the preparation of the budget.

4) Due to several constraints on the quantity and/or quality of the factors of production available to the firm, it is likely that managers have to choose a preference order for values. The budget can be prepared by starting with the implementation of the values that have priority over others. Choices about priorities are made on the basis of a moral judgment in the sense indicated earlier.

5) The key factor in this model is on the introduction of values into Activity-Based Budgeting. More specifically, the budgeting process is carried out by incorporating the values into each single element of every activity. The system is simulated to evaluate the efficiency and effectiveness of all activities. Software provides detailed operational and financial reports on each activity and on the system as a whole.

The model proposed in this paper has important implications. The key points underlined in the model can help managers to try to integrate effectively the values into the planning system because of the flexible and intuitive Activity-Based Budgeting approach, the integration of values in budgeting should also have personal effects on managers' lives. Ethical behavior could be seen as a prerequisite for a happy life and for future action in the pursuit of higher human values (Rego, Ribeiro, \& Cunha, 2010; Fu et al. 2010). This study, however, has some 
limitations. Although this method is implemented in some firms as described in the sixth section, the integration of values into Activity-Based Budgeting has received formally little attention in both research literature and real life. We await the empirical evidence to confirm or refute the proposal suggested in this paper.

\section{References}

Adam, A. M., \& Rachman-Moore, D. (2004). The methods used to implement an ethical code of conduct and employee attitudes. Journal of Business Ethics, 54, 225-244. http://dx.doi.org/10.1007/s10551-004-1774-4

Bommer, M., Gratto, C., Gravander, J., \& Tuttle, M. A. (1987). A behavioral model of ethical and unethical decision making. Journal of Business Ethics, 6, 265-280. http://dx.doi.org/10.1007/BF00382936

Bonn, I., \& Fisher, J. (2005). Corporate governance and business ethics: insights from the strategic planning experience. Corporate Governance: An International Review, 13(6), 730-738. http://dx.doi.org/10.1111/j.1467-8683.2005.00466.x

Brenkert, G. G. (2010). The limits and prospects of business ethics. Business Ethics Quarterly, 20(4), 703-709. http://dx.doi.org/10.5840/beq201020444

Brimson, J. A., \& Antos, J. (1999). Driving value using Activity-Based Budgeting. New York, NY: Wiley.

Bunce, P., Fraser, R., \& Woodcock, L. (1995). Advanced budgeting: a journey to advanced management systems. Management Accounting Research, 6, 253-265. http://dx.doi.org/10.1006/mare.1995.1017

Carasco, E. F., \& Singh, J. B. (2003). The content and focus of the codes of Ethics of the world's largest transnational corporations. Business and Society Review, 108, 71-94. http://dx.doi.org/10.1111/1467-8594.00007

Casey, D. P., \& Wier, B. (2000). Integrating Ethical Dimensions into a Model of Budgetary Slack Creation. Journal of Business Ethics, 28, 267-277. http://dx.doi.org/10.1023/A:1006241902011

Cressey, D. R., \& Moore, C. A. (1983). Managerial values and corporate Codes of Ethics. California Management Review, 25(4), 53-77. http://dx.doi.org/10.2307/41165032

Cullen, J. B., Praveen, P. K., \& Bart, V. (2003). The effects of ethical climates on organizational commitment. Journal of Business Ethics, 46, 127-141. http://dx.doi.org/10.1023/A:1025089819456

De Finance, J. (1997). Etica generale. Roma, Italia: Editrice Pontificia Università Gregoriana.

Dierksmeier, C. (2011). The freedom-responsibility nexus in management philosophy and business ethics. Journal of Business Ethics, 101, 263-283. http://dx.doi.org/10.1007/s10551-010-0721-9

Drascek, M., \& Maticic, S. (2008). What Managers Could See in the Philosophical Block of "Free Will'? Journal of Business Ethics, 81, 1-14. http://dx.doi.org/10.1007/s10551-007-9476-3

Drucker, P. (1956). The practice of management. New York, NY: Harper \& Row.

Dubinsky, A. J., \& Loken, B. (1989). Analyzing ethical decision making in marketing. Journal of Business Research, 19(2), 83-107. http://dx.doi.org/10.1016/0148-2963(89)90001-5

Ekholm, B. G., \& Wallin, J. (2000). Is the annual budget really dead? The European Accounting Review, 9(4), 519-539. http://dx.doi.org/10.1080/09638180020024007

Ethics Resource Center. (2012). 2011 National business ethics survey: workplace ethics in transition. Arlington, VA.

Ferrell, O. C., Fraederic, J., \& Ferrell, L. (2011). Business ethics: ethical decision making and cases. Mason, $\mathrm{OH}$ : South-Western Cengage Learning.

Ferrell, O., \& Gresham, L. (1985). A contingency framework for understanding ethical decision-making in marketing. Journal of Marketing, 49(3), 87-96. http://dx.doi.org/10.2307/1251618

Ford, R. C., \& Richardson, W. D. (1994). Ethical decision making: a Review of the empirical literature. Journal of Business Ethics, 13, 205-221. http://dx.doi.org/10.2307/1251618

Fu, P. P., Tsui, A. S., Liu, J., \& Li, L. (2010). Pursuit of whose happiness? Executive leaders' transformational behaviors and personal values. Administrative Science Quarterly, 55, 222-254. http://dx.doi.org/10.2189/asqu.2010.55.2.222

Grojean, M. W., Resick, C. J., Dickson, M. W., \& Brent, S. D. (2004). Leaders, values, and organizational climate: examining leadership strategies for establishing an organizational climate regarding ethics. Journal of Business Ethics, 55, 223-241. http://dx.doi.org/10.1007/s10551-004-1275-5 
Guerrette, R. H. (1988). Corporate ethical consulting: developing management strategies for corporate ethics. Journal of Business Ethics, 7, 373-380. http://dx.doi.org/10.1007/BF00382540

Haines, R., Street, M. D., \& Haines, D. (2008). The influence of perceived importance of an ethical issue on moral judgment, moral obligation, and moral intent. Journal of Business Ethics, 81, 387-399. http://dx.doi.org/10.1007/s10551-007-9502-5

Hansen, S. C. (2011). A Theoretical analysis of the impact of adopting rolling budgets, Activity-Based Budgeting and Beyond Budgeting. European Accounting Review, 20(2), 289-319. http://dx.doi.org/10.1080/09638180.2010.496260

Hansen, S. C., Otley, D. T., \& Van der Stede, W. A. (2003). Practice developments in budgeting: an overview and research perspective. Journal of Management Accounting Research, 15, 95-116. http://dx.doi.org/10.2308/jmar.2003.15.1.95

Hart, S. L. (1971). Axiology-Theory of Values. Philosophy and Phenomenological Research, 32(1), 29-41. http://dx.doi.org/10.2307/2105883

Helin, S., \& Sandström, J. (2007). An inquiry into the study of corporate codes of ethics. Journal of Business Ethics, 75, 253-271. http://dx.doi.org/10.1007/s10551-006-9251-x

Ho, C. M. F. (2010). A critique of corporate ethics codes in Hong Kong construction. Building Research \& Information, 38(4), 411-427. http://dx.doi.org/10.1080/09613211003665125

Hobson, J. L., Mellon, M. J., \& Stevens, D. E. (2011). Determinants of moral judgments regarding budgetary slack: an experimental examination of pay scheme and personal values. Behavioral Research in Accounting, 23(1), 87-107. http://dx.doi.org/10.2308/bria.2011.23.1.87

Hope, J., \& Fraser, R. (2000). Beyond budgeting. Strategic Finance, 82(4), 30-35.

Hope, J., \& Fraser, R. (2003). Who Needs Budgets? Harvard Business Review, 81(2), 108-115.

Hosmer, L. T. (1994). Strategic planning as if ethics mattered. Strategic Management Journal, 15, 17-34. http://dx.doi.org/10.1002/smj.4250151003

Human Rights Council. (2011). Guiding Principles on Business and Human Rights: Implementing the United Nations "Protect, Respect and Remedy" Framework. United Nations, A/HRC/17/31.

Hunt, S. D., \& Vitell, S. (1986). A general theory of marketing ethics. Journal of Macromarketing, 6(1), 5-16. http://dx.doi.org/10.1177/027614678600600103

Jensen, M. C. (2003). Paying people to lie: the truth about the budgeting process. European Financial Management, 9(3), 379-406. http://dx.doi.org/10.1111/1468-036X.00226

Jones, T. M. (1991). Ethical decision making by individuals in organizations: an issue-contingent model. Academy of Management Review, 16(2), 366-395.

Kane, R. (1998). The significance of free will. Oxford, UK: Oxford University Press.

Kaptein, M. (2004). Business codes of multinational firms: what do they say? Journal of Business Ethics, 50(1), 13-31. http://dx.doi.org/10.1023/B:BUSI.0000021051.53460.da

Kaptein, M. (2011). Toward effective codes: testing the relationship with unethical behavior. Journal of Business Ethics, 99, 233-251. http://dx.doi.org/10.1007/s10551-010-0652-5

Kaptein, M., \& Schwartz, M. S. (2008). The effectiveness of business codes: a critical examination of existing studies and the development of an integrated research model. Journal of Business Ethics, 77, 111-127. http://dx.doi.org/10.1007/s10551-006-9305-0

Kohlberg, L. (1969). Stage and Sequence: the Cognitive-Developmental Approach to Socialization. In D. A, Goslin (Ed.), Handbook of Socialization Theory and Research (pp. 347-480). Chicago, IL: Rand-McNally.

KPMG Forensic. (2008). Integrity Survey 2008-2009, KPMG LLP.

Lau, C. M., \& Tan, L. S. C. (1996). The effects of procedural fairness and interpersonal trust on job tension in budgeting. Management Accounting Research, 27(1), 171-186.

Leavitt, K., Reynolds, S. J., Barnes, C. M., Schilpzand, P., \& Hannah, S. T. (2012). Different hats, different obligations: plural occupational identities and situated moral judgments. Academy of Management Journal, 55(6), 1316-1333. http://dx.doi.org/10.5465/amj.2010.1023

Lere, J. C., \& Gaumnitz, B. R. (2003). The impact of codes of ethics on decision making: some insights from 
information economics. Journal of Business of ethics, 48, 365-379. http://dx.doi.org/10.1023/B:BUSI.0000005747.37500.c8

Lere, J. C., \& Gaumnitz, B. R. (2007). Changing Behavior by Improving Codes of Ethics. American Journal of Business, 22(2), 7-17. http://dx.doi.org/10.1108/19355181200700006

Libby, T. (2001). Referent Cognitions and Budgetary Fairness: A Research Note. Journal of Management Accounting Research, 13, 91-105. http://dx.doi.org/10.2308/jmar.2001.13.1.91

Libby, T., \& Lindsay, R. M. (2010). Beyond budgeting or budgeting reconsidered? A survey of North-American budgeting practice. Management Accounting Research, 21, 56-75. http://dx.doi.org/10.1016/j.mar.2009.10.003

Loe, T. W., Ferrell, L., \& Mansfield, P. (2000). A review of empirical studies assessing ethical decision making in business. Journal of Business Ethics, 25, 185-20. http://dx.doi.org/10.1023/A:1006083612239

Loviscky, G. E., Trevino, L. K., \& Jacobs, R. R. (2007). Assessing managers' ethical decision making: an objective measure of managerial moral judgment. Journal of Business Ethics, 73, 263-285. http://dx.doi.org/10.1007/s10551-006-9206-2

Marcino, G. R. (2000). Obliterate traditional budgeting. Financial Executive, 16(6), 29-31.

McKendall, M., DeMarr, B., \& Jones-Rikkers, C. (2002). Ethical compliance programs and corporate illegality: testing the assumptions of the corporate sentencing guidelines. Journal of Business Ethics, 37(4), 367-383. http://dx.doi.org/10.1023/A:1015287823807

Mingers, J., (2011). Ethics and OR: operationalising discourse ethics. European Journal of Operational Research, 210, 114-124. http://dx.doi.org/10.1016/j.ejor.2010.11.003

O'Fallon, M., \& Butterfield, K. D. (2005). A review of the empirical ethical decision-making literature: 1996-2003. Journal of Business Ethics, 59, 375-413.

O'Connor, T. (2013). Free Will. In E. N. Zalta (Ed.), The Stanford Encyclopedia of Philosophy. Retrieved from http://plato.stanford.edu/archives/spr2013/entries/freewill/

Ormerod, R. J., \& Ulrich, W. (2013). Operational research and ethics: a literature review. European Journal of Operational Research, 228, 291-307. http://dx.doi.org/10.1016/j.ejor.2012.11.048

Pinckaers, S. (1992). Le fonti della morale cristiana: metodo, contenuto, storia. Milano. Italia: Ares.

Rampersad, H. K. (2003). Linking self-knowledge with business ethics and strategy development. Business Ethics: A European Review, 12(3), 246-257. http://dx.doi.org/10.1111/1467-8608.00324

Randall, D. M., \& Gibson, A. M. (1990). Methodology in business ethics research: a review and critical assessment. Journal of Business Ethics, 9, 457-471. http://dx.doi.org/10.1007/BF00382838

Rego, A., Ribeiro, N., \& Cunha, M. P. (2010). Perceptions of organizational virtuousness and happiness as predictors of organizational citizenship behaviors. Journal of Business Ethics, 93, 215-235. http://dx.doi.org/10.1007/s10551-009-0197-7

Rest, J. R. (1986). Moral development: advances in research and theory. New York, NY: Praeger Publishers.

Robin, D., \& Reidembach, R. E. (1987). Social responsibility, ethics and marketing strategy: closing the gap between concept and application. Journal of Marketing, 51, 44-58. http://dx.doi.org/10.2307/1251143

Rocco Cottone, R., \& Claus, R. E. (2000). Ethical decision-making models: a review of the literature. Journal of Counseling and Development, 78, 275-283. http://dx.doi.org/10.1002/j.1556-6676.2000.tb01908.x

Rockwell Automation. (2006). Arena 11.0. USA: Rockwell Automation Technologies Inc.

Schmidt, J. A. (1992). Is it time to replace traditional budgeting? A method to make a budget more useful to management is proposed. Journal of Accountancy, 174(4), 103-107. http://dx.doi.org/10.1007/s10551-005-3403-2

Schroeder, M. (2012). Value Theory. In E. N. Zalta (Ed.), The Stanford Encyclopedia of Philosophy. Retrieved from http://plato.stanford.edu/archives/sum2012/entries/value-theory/

Schwartz, M. S. (2005). Universal moral values for corporate codes of ethics. Journal of Business Ethics, 59, $27-44$.

Shaw, H. (2005). Business ethics. Belmont, CA: Thomson Wadsworth. 
Singh, J. B. (2011). Determinants of the effectiveness of corporate codes of ethics: an empirical study. Journal of Business Ethics, 101, 385-395. http://dx.doi.org/10.1007/s10551-010-0727-3

Singh, J., Svensson, G., Wood, G., \& Callaghan, M. (2011). A longitudinal and cross-cultural study of the contents of codes of ethics of Australian, Canadian and Swedish corporations. Business Ethics: A European Review, 20(1), 103-119. http://dx.doi.org/10.1111/j.1467-8608.2010.01612.x

Stead, W. E., Worrell, D. L., \& Stead, J. G. (1990). An integrative model for understanding and managing ethical behavior in business organizations. Journal of Business Ethics, 9, 233-242. http://dx.doi.org/10.1007/BF00382649

Stevens, B. (2008). Corporate ethical codes: effective instruments for influencing behavior. Journal of Business Ethics, 78, 601-609. http://dx.doi.org/10.1007/s10551-007-9370-z

Street, M. D., Douglas, S. C., Geiger, S. W., \& Martinko, M. J. (2001). The Impact of cognitive expenditure on the ethical decision-making process: the cognitive elaboration model. Organizational Behavior and Human Decision Processes, 86(2), 256-277. http://dx.doi.org/10.1006/obhd.2001.2957

Trevino, L. K. (1986). Ethical decision making in organizations: a person-situation interactionist model. Academy of Management Review, 11, 601-617.

Trevino, L. K., Butterfield, K. D., \& McCabe, D. L. (1998). The ethical context in organizations: Influences on employee attitudes and behaviors. Business Ethics Quarterly, 8(3), 447-476. http://dx.doi.org/10.2307/3857431

Valentine, S. (2009). Ethics Training, Ethical context, and sales and marketing professionals' satisfaction with supervisor and co-workers. Journal of Personal Selling \& Sales Management, 29(3), 227-242. http://dx.doi.org/10.2753/PSS0885-3134290302

Valentine, S., \& Barnett, T. (2003). Ethics code awareness, perceived ethical values, and organizational commitment. Journal of Personal Selling \& Sales Management, 23(4), 359-367.

Velasquez, M. G. (2006). Business ethics, concept and cases. Upper Saddle River, NJ: Pearson Prentice Hall.

Vendemiati, A. (2004). In prima persona; lineamenti di etica generale. Roma, Italia: Urbaniana University Press.

Wallander, J. (1999). Budgeting-an unnecessary evil. Scandinavian Journal of Management, 15, 405-421. http://dx.doi.org/10.1016/S0956-5221(98)00032-3

Waters, J. A., \& Bird, F. (1987). The moral dimension of organizational culture. Journal of Business Ethics, 6 , 15-22. http://dx.doi.org/10.1007/BF00382944

Weber, J., \& McGivern, E. (2010). A new methodological approach for studying moral reasoning among managers in business settings. Journal of Business Ethics, 92, 149-166. http://dx.doi.org/10.1007/s10551-009-0146-5

Webley, S., \& Werner, A. (2008). Corporate codes of ethics: necessary but not sufficient. Business Ethics: a European Review, 17(4), 405-415. http://dx.doi.org/10.1111/j.1467-8608.2008.00543.x

Weiss, J. W. (2006). Business ethics: a stakeholder and issues management approach. Mason, OH: Thomson South-Western.

\section{Copyrights}

Copyright for this article is retained by the author(s), with first publication rights granted to the journal.

This is an open-access article distributed under the terms and conditions of the Creative Commons Attribution license (http://creativecommons.org/licenses/by/3.0/). 